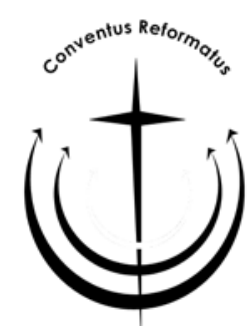

\title{
Calvin, Augustine of Hippo and South Africa: in discussion with Johannes van Oort
}

\author{
J.W. Hofmeyr \\ Department of Ecclesiology \\ University of the Free State \\ BLOEMFONTEIN \\ E-mail: linhof@mweb.co.za
}

\section{Abstract \\ Calvin, Augustine of Hippo and South Africa: in discussion with Johannes van Oort}

In this article the curtain is raised on the interesting and fascinating relation between Augustine of Hippo and John Calvin from Geneva, as seen through the eyes of the Dutch scholar Johannes van Oort. The influences of and links between Augustine and Calvin are immense. This has been the focus of various studies in the past. The purpose of this article is, however, not to re-invent the wheel about these relations, but rather to reflect on one of the most eminent scholars on Augustine, i.e. Van Oort's vision on these links and to enter into a dialogue with him so as to shed some new light on this topic and on some aspects related to ecclesiology. After attention to the use of Augustine by Calvin, the focus is on the discussion with Van Oort and eventually on the relevance of this for us in South(ern) Africa. It is concluded that in this era of postmodernism and relativism as well much can be learnt from both Augustine and Calvin, and especially with regard to the wellbeing of the church.

\section{Opsomming}

Calvyn, Augustinus van Hippo en Suid-Afrika: in gesprek met Johannes van Oort

In hierdie artikel word die gordyn gelig op die besonder interessante en boeiende band tussen Augustinus van Hippo en Johannes Calvyn van Genève soos gesien deur die bril van Johannes van Oort. Die invloede en verbintenisse tussen Au- 
gustinus en Calvyn is geweldig omvattend. Hierdie studieonderwerp het alreeds in die verlede baie aandag gekry. Die doel van hierdie artikel is egter nie om die wiel te herontwerp nie, maar eerder om na te dink oor enkele ekklesiologiese aspekte en nuwe lig te werp op een van die mees vooraanstaande, eietydse kenners van Augustinus, naamlik Johannes van Oort se denke hieroor asook om met hom in gesprek te tree. Nadat aandag gegee is aan die aanwending van Augustinus deur Calvyn self, word 'n aantal vrae aan Van Oort gerig. Hierna word die relevansie daarvan vir Suid-Afrika onder die loep geneem. Daar word tot die gevolgtrekking gekom dat selfs in hierdie era van postmodernisme en relativisme baie van Augustinus en Calvyn geleer kan word, veral ook met betrekking tot die welwese van die kerk.

\section{Introduction}

The attention for John Calvin in this 500th celebrations year of his birth in 1509 is of special importance also for us living on the outskirts of his world of influence. In this era of postmodernism, relativism and revisionism influencing virtually every aspect of our society and also of theology, it is of the utmost importance to come to a new understanding, but also a new appreciation of the traditions that we are part of. Naturally, especially in this year of celebrations, we ought to be very sensitive to and careful of hagiography. On the other hand we are not going to make much progress in our contemporary way of thinking about society or theology if we are not once again able to go back to our tradition and sources, ad fontes, so as to re-evaluate our position and reconsider the road ahead. We need to be very careful not to judge people and movements in history according to our own current ideas, paradigms and mindsets, but to look at them as products and children of their times. This also applies to Calvin.

In this article, being aware as an historian of the pitfalls and the challenges of our times, I find it important to shed new light and to go into a discussion with Van Oort, one of the top current Augustine scholars from Utrecht in the Netherlands on the relations between John Calvin and Augustine of Hippo. It is precisely because of his scholarship on this relationship together with his very specialised knowledge of Augustine that this is an important and stimulating endeavour also for us here in South(ern) Africa. We are indeed privileged as South Africans to have him involved in local academic circles and discussions. 


\section{Calvin's use of Augustine of Hippo according to Johannes van Oort}

Various influential historical studies have been undertaken in the field of Calvin's links and relation with Augustine, besides those done by Johannes van Oort. We briefly wish to focus on them.

Between 1956 and 1958 the Louvain student Luchesius Smits published two very important volumes on Augustine's influence in the works of Calvin: Saint Augustin dans l'œuvre de Jean Calvin. He addresses the central significance of Augustine for Calvin and he refers among other issues also to the doctrine of predestination. In this seminal study Smits managed to cover most of Calvin's publications in his analysis of the influence of Augustine on Calvin. In 1964 Todd published The function of the patristic writings in the thought of John Calvin. In 1965 the doctor from Utrecht University, Mooi, published another interesting overview of the Reformer's knowledge and judgement of the church fathers titled Het kerk- en dogmahistorisch element in de werken van Johannes Calvijn. In 1974 the first thematic study of Calvin's use of Chrysostom was addressed in a Ph.D. thesis at the University of Pittsburg in the USA by Walchenbach with the title John Calvin as biblical commentator: an investigation into Calvin's use of Chrysostom as an exegetical tutor. An interesting comparison between Calvin and the church fathers like Augustine, Tertullian and Irenaeus was published by Meijering in 1980 with the title Calvin wider die Neugierde: ein Beitrag zum Vergleich zwischen reformatorischem und patristischem Denken. In some ways the above thesis by Walchenbach was paralleled in 1981 by Ganoczy and Müller's Calvins handschriftlichen Annotationen zu Chrysostomus: ein Beitrag zur Hermeneutik Calvins. Also in 1981 Lane published the first important and extensive overview in English of Calvin's use of his patristic and medieval predecessors in Calvin's use of the fathers and the medievals in Calvin theological journal.

In 1990 Lange van Ravenswaaij published a book on Calvin's understanding of Augustine based on his 1986 Tübingen thesis. It has the title Augustinus totus noster: das Augustin-Verständnis bei Johannes Calvin. Van Oort (1992) at a stage goes into a fairly comprehensive and critical discussion of this thesis in a review article published in the well known Dutch journal Dutch review of church history.

Van Oort (1992) first of all critically explains the contents of this publication. In an introduction Lange van Ravenswaaij (1990) fo- 
cuses on the parameters of his study. According to him, in spite of lots of attention to Augustine and Calvin's relationship, little has been done in terms of the understanding of Augustine by Calvin ("Calvins Augustin-Verständnis"). In a first chapter the author deals with the doctrine of predestination with Augustine and Calvin. Though he develops many resemblances, there are also major differences between their positions. In chapter two Lange van Ravenswaaij provides in chronological order an overview of Calvin's major publications and Augustine's place in them. Calvin often follows the line of firstly referring to Scriptures, secondly to Augustine and only then coming to an own viewpoint. Lange van Ravenswaaij, however, did not make a special effort to study Calvin's sermons and letters. In the following chapters the author attends to aspects like how the relationship between Scriptures and tradition influenced Calvin's understanding of Augustine, how Augustine influenced Calvin's view of history, and also Calvin's self-understanding in the light of Augustine. In a final chapter Lange van Ravenswaaij focuses on the influences of others on Calvin's knowledge and understanding of Augustine. Lange van Ravenswaaij concludes that the question about the understanding of Augustine by Calvin

... heeft (betrekking) op het centrum van de theologie en de persoon van de reformator. De bepaling van Calvijns positie t.o.v. Augustinus is de sleutel op weg naar een 'neudefinition der Koordinaten der Theologie des Genfer Reformators. An keiner anderen Stelle als in der Bestimmung seines AugustinVerständnisses kann somit besser erwiesen werden, wer Calvin ist.' (Van Oort, 1992:94.)

Van Oort (1992) finally concludes, in my opinion correctly, that this is an important and stimulating study. It, however, does not contain the final word on the relationship between Calvin and Augustine.

Meer nog en breder zal gezocht moeten worden naar het 'Augustinverständnis' van Calvijn, niet slechts in de predestinatieleer maar ook betreffende de sacramenten, de rechtvaardigingsleer, de (erf)zonde, de visie op de geschiedenis, de ecclesiologie en bijv. de waardering van ascese in het algemeen en Augustinus' monachisme in het bijzonder. (Van Oort, 1992:103.)

Though he concludes that the author has not succeeded in declaring "Augustinus totus noster" and that Calvin did not initiate a new "Augustine School", Lange van Ravenswaaij has amply proved that without a deep knowledge of Augustin the reformer Calvin cannot be properly understood. 
Because of the goal of this essay, i.e. a discussion with Johannes van Oort it is for our purposes more important to specifically focus on Johannes van Oort's views on the way in which Calvin related to Augustine of Hippo. Only then it will be able to properly dialogue with him and consider and judge Calvin's use of the church fathers in general, and more specifically of Augustine himself.

According to Van Oort up till recently the use of specific sources by Calvin has not been studied comprehensively. Naturally being a reformer he was a theologian who linked up closely with Scriptures but the witness of the early church fathers was also of great importance to him.

When one studies Calvin's œuvre, it is clear that in some of his very earliest works he already reflects on his links with the Early Church. Already in 1532 in his commentary on the Roman philosopher's work De Clementia he indicates his knowledge and use of this early church period. He also, at this stage, refers to Augustine of Hippo's De Civitate.

In 1535 in his Latin foreword to the French Bible translation of Robert Olivétan he mentions that the independent reading and study of the Scriptures was not a new endeavour at this stage. Already in the early centuries did church fathers like Chrysostom, Jerome and especially Augustine plead for this approach.

Even clearer was Calvin's appeal to the church fathers in his letter dated 23 August 1535 addressed to the famous king Francis 1. It was added as an introduction to his first edition of the Institutes (1536). It is being regarded as an impressive example of apologetics as practised by Calvin. Calvin indicates in this letter to the king that the latter must realise that those reformers who are a new reality to French society must not be judged on a par with the sectarian Anabaptists of that era. On the contrary, they are no revolutionaries and they are actually not really new, because they are Catholic and have their origins in early times already. He indicates that current Catholic teaching stood in conflict with that of the Early Church. He continues to state that the teaching of the Reformation closely links up with that of the church fathers.

The first edition or version of the Institutes (1536) "follows the classical plan of Luther's catechisms: Law, Creed, Lord's Prayer, sacraments of Baptism and Communion, false sacraments, Christian liberty ..." (Cottret, 2000:310). Also in this first edition of Calvin's Institutes, according to Van Oort, it is very clear how closely Calvin 
felt towards the Early Church. In the margins of this edition he first of all refers to Scriptures. Besides that, he reflects his position as an Humanist and he quite often refers to the ancient philosopher Plato. The fact that he was fairly knowledgeable with the church fathers is very clear from these marginal notes. It is most probably legitimate to conclude that besides getting his citations elsewhere, he definitely read some of the church fathers himself. His references include those to Augustine, Cyprian, Jerome and Ambrose. In his debate with the Roman Catholics they function as authorities and he clearly wishes to position himself in line with these early church fathers. Besides, he even attacks the Catholics about their views as related to various aspects in scholasticism, while using the church fathers. $\mathrm{He}$, for instance, refers to questions such as the purpose of sophistic arguments and false distinctions as it relates to the sacraments. According to Calvin they could better use and read Augustine and that would greatly benefit them.

In the Religious Disputation of Lausanne (1536) Calvin is once again in dialogue with the Roman Catholics about the sacraments, and more specifically about Holy Communion and the issue of transubstantiation. Attending this Disputation as well were Viret and Farel. Though Calvin as the junior partner initially said little, he gradually partook to a greater extent. Particularly impressive were Calvin's arguments taken from the early church fathers. Not only did the reformer read them extensively, but he was also educated and influenced by them. To some great length Calvin quoted extensive passages from Cyprian, Tertullian and especially Augustine. The witness of the fathers (testimonium patrum) and especially that of Augustine was very strong on issues like the sacraments, ecclesiology, and his views on grace and predestination.

The second version of Calvin's Institutes (1539) adds to the structure of the first edition, which has been referred to above,

... a patristic, or more precisely Augustinian, porch. The knowledge of God precedes self-knowledge; original sin is clearly affirmed. Justification by faith, criticism of the merit of works, Christian liberty, and predestination receive substantial development. This second version clearly represents a constitution for a Reformed or Calvinist church, distinct from other currents of reform. (Cottret, 1995:310.)

The testimonium patrum was, however, also very apparent in debates with a Lutheran like Westphal, with Bolzec and with Servetus. Besides that, the use of more specifically Augustine in the debate 
with Pighius from Kampen in the Netherlands was very obvious. The latter published a book in 1542 relating to God's grace and the (un)free will of mankind, referring to Augustine extensively. In Calvin's Defensio of almost 240 pages he quotes Augustine virtually on every page. Calvin criticises Pighius for his rather conservative method and approach: he does not take enough note of the context of Augustinian texts, but rather ends up in providing an anthology of citations. Besides, by quoting pseudo-Augustiniana, Pighius also reflects his lack of a proper knowledge of Augustine. Calvin is also to be commended for the hermeneutical principles that he follows: he feels strongly about the fact that Augustine must be studied and read from the perspective of his later works, i.e. his anti-Pelagian position.

Van Oort at a stage discusses Calvin's second period in Geneva and especially how he uses Augustine in the fifth and final Latin version of his Institutes in 1559. He comes to the following conclusion about this period, and this also applies in many ways to Calvin's appreciation of Augustine in general: he is cited as the patristic authority par excellence. The sheer number of references gives a clear indication of the place of Augustine in Calvin's theology. Augustine is particularly prominent in the chapters which discuss that "man has now been deprived of freedom of choice and bound over to miserable servitude" (Inst. 2.2) so that "only damnable things come forth from man's corrupt nature" (Inst. 2.3) and also in the related chapter which aims to refute any defense of free will (Inst. 2.5). In referring to various aspects of Augustine's influence in Calvin's theology, according to Van Oort (1997a:683), "Calvin claims an essential conformity between Augustine and Reformed theology", especially with reference to anti-Pelagianism. It is finally "above all the claimed conformity with Augustine that became a characteristic feature of Calvin's most influential work" (Van Oort, 1997a:684).

Though Calvin definitely used Augustine's views and publications very extensively in his own thinking and theologising, he also had quite a knowledge of and exposure to Chrysostom as an exegete and to Cyprian and Ambrose with regard to their views on ecclesiology, justification and the relationship between church and state. $\mathrm{He}$ was also well informed about Irenaeus, Tertullian, Cyril from Alexandria and even to Bernard of Clairvaux. Whether Calvin knew them first hand is not known, but it is unlikely and virtually impossible to have had a specialised knowledge of all of them. At least, as an able humanist he read many of them and he also had the capability of referring to them in an able way. 
With regard to the central issues in Calvin's theology like his ecclesiology, his doctrine of sin and grace as well as the sacraments, there is a continuing appeal to Augustine as his most prominent source among the patristic authors. In some ways it is, however, a pity that Van Oort did not expand in some greater detail on the issue of ecclesiology with Augustine and Calvin. It, however, has finally to be stated that for Calvin as for the other reformers,

\begin{abstract}
the Church Fathers were only subsidiary authorities. The fact that he treated them as authorities might reflect his legal background ... [H]owever, Scripture alone he considered to be his norm and the sole basis for his argument. Notwithstanding this, the testimony of the Fathers was welcomed, and usually the accuracy of his quotations was high by the standards of his day. Thus Calvin ... turns out to be an excellent representative of the sixteenth-century reception of the Church Fathers in the West. (Van Oort, 1997a:699.)
\end{abstract}

As is clear from the above we have to conclude that we are indeed greatly indebted to Johannes van Oort for his very valuable insights into a fascinating facet of theological history. Without his input we would have been so much the poorer.

\title{
3. In discussion with Johannes van Oort
}

To engage, besides the elements of discussion above, in further discussion with Johannes van Oort in terms of his views on this topic is indeed an interesting exercise on an academic level. He comes from a well balanced theological and ecclesiastical background. Van Oort can be regarded as one of the top European scholars of our times on Augustine of Hippo. He has not only extensively researched, but has also widely published his research on Augustine in a wide range of publications.

My brief discussion with Johannes van Oort will largely focus on a couple of questions to him. Where necessary I will briefly expand on them.

First of all, I would like to address to Van Oort as an eminent scholar of Augustine the question to what extent, if any, did Augustine's African background and context have an influence on Calvin, also in terms of his ecclesiology. Though most probably not directly, I presume that there possibly could have been indirect influences. With reference to the relations between Augustine and Calvin, how does one respond to the American scholar David Steinmetz' statement that "[a]ll the Reformers loved Augustine ... the Reformation is (in 
part) about the early fathers, whom the Protestants wanted to claim" (Noll \& Nystrom, 2005:195); what does one make of the prominent American scholar Mark Noll who concurs with Steinmetz and others that the Reformers "appreciated these early figures as models ... because they wanted to be connected to their spiritual ancestors" (Noll \& Nystrom, 2005:195); and how does one respond to the American scholar John Hesselink who regards Calvinism as Augustinianism, "an exaltation of the sovereign grace of God" (Hesselink, 1983:95).

Secondly, I would like to know from Van Oort how it affects theologising in South Africa, with regard to ecclesiology, if we speculate that both Augustine and Calvin, even indirectly through Augustine, have been exposed to some African realities and influences. In this respect I would like to know from Van Oort how he, for instance, views through the eyes of Augustine and Calvin, the aspect of state optimism and pessimism, an issue that we in South(ern) African church circles battle with quite regularly both in the past and also currently. Augustine so clearly states it in De civitate Dei as quoted by the prominent South African scholar Van Wyk (2005:348): "Want watter ander einde is daar vir ons as om die koninkryk te bereik wat nooit 'n einde sal hê nie". Van Wyk (2005:349) continues in this respect about the current South African context:

Hierdie boodskap van die biskop uit Noord-Afrika het veral vir Afrikaners in Suid-Afrika besondere betekenis ... (wat) na die demokratiese oorgang in 1994 letterlik alle politieke mag verloor (het). Augustinus se boodskap los wel nie alle politieke vrae op nie, maar hy herinner Christene aan die verganklikheid, voorlopigheid en gebrokenheid van alle aardse ryke.

Thirdly, I would like to know from Van Oort what direct or indirect dimensions have been added to Augustine's influence on Calvin especially with regard to ecclesiology, also via the Catholic Middle Ages and Scholasticism. What does he make of the fact that Calvin almost always quoted favourably from eleven works by Bernard of Clairvaux (Noll \& Nystrom, 2005:51).

In the fourth instance I would like Van Oort to respond to the question about Augustine's influence on Calvin with regard to religious experience in the church and in personal belief. Is it correct to assume that Calvin's reserved position on this can, as indicated by the Dutch theologian H.J. Selderhuis, be attributed to the Augustinian tradition. It is important in this respect to refer to the remark in the 
Louvain Th.D. thesis of Hans Geybels (2004:237): “... gevoelens kunnen bezit nemen van de mens en bijgevolg van God afleiden".

In the fifth instance I would like to ask Van Oort how the knowledge of and insight into the contributions of Augustine and Calvin can provide guidelines in the current ecclesiological debate in some South African circles, and their experimenting with theological liberalism and relativism under the flag and influence of the so-called New Reformation Network. To what extent does he concur with Steinmetz that the reformers regarded innovation as heresy when he said:

The Reformation was not an argument about everything, but about just some things. It was not, for example about the Trinity or the two natures of Christ ... If we ask where these accepted doctrines came from - they came from the Fathers' reflections on the Bible. (Noll \& Nystrom, 2005:196.)

A next question to this is what role the views of Augustine and Calvin can play in the issue of church unity and Christian love over against the holiness of the church. A further question would be the debate about the church as the body of Christ (corpus Christi), which was very central both to Augustine and to Calvin. This perspective has serious implications for the unity of the church. Van Oort himself, together with Augustine, strongly feel about the issue of division in the church and a church without love. For Augustine love is actually the hermeneutical key to understand Scriptures (Van Wyk, 2005:349). Van Oort confirms this in his statement: "Het diepste wezen van de kerk is voor Augustinus de liefdesgemeenschap in de Heilige Geest" (Van Wyk, 2005:349). As indicated by Van Wyk in a seminal essay on Christian identity, Augustine can help us to quite a large extent along the road of the unity and holiness of the church:

Daarom kan 'n studie van die geskrifte van die groot kerkvader uit Noord-Afrika ons dalk help om weer 'n passie vir die eenheid van die kerk van Christus te ontwikkel, maar dan 'n passie wat deurtrek is van die liefde, liefde vir Christus en sy kerk, ja, vir God en sy koninkryk. (Van Wyk, 2005:354.)

Finally I wish to ask Van Oort what specific contributions can be made by South African theologians as they relate to the South African theological and ecclesiological debate with reference to the continuing discussion on Calvin and his links with the church fathers. 


\section{The relevance for South Africa}

Some issues gained from our discussion on Augustine and Calvin, need our attention to address the issue of its ecclesiological relevance for our times and context.

It is, first of all, abundantly clear from reading Augustine and also about the Reformation, as initiated by Calvin and others, that mankind is saved by grace through faith in Jesus Christ alone. People no longer looked upon the church as the institution that held the key to salvation as was the case with the Roman Catholic Church. Justification by grace through faith in Jesus Christ does not imply idle faith but participatory faith. It means that like Christ Himself we need to participate by living a life according to Christ's teaching and example. Both the above issues are of special relevance for the current postmodernist debates focusing especially on Christology and soteriology in South Africa.

A second aspect relates to the issue of predestination. The doctrine of predestination as developed by Calvin and most probably under the influence of Augustine is open to various interpretations. Besides a sound understanding of this rather complex Calvinistic doctrine, it has in the course of history sometimes been wrongly applied and interpreted which sadly sometimes bred fanatic elements. This is also a phenomenon in the South African context with special reference to the idea of the chosen people as developed by some groups in society.

A third aspect which is very relevant for our times is the issue of Calvin's hermeneutical principles overriding his exegetical rules, at least in some cases like the exegesis of Romans 7. Ward Holder (2005:3) goes into a rather deep discussion of this issue and concludes as follows:

[1]t was natural for Calvin to turn to Augustine, because Augustine was Calvin's favourite patristic source. As he turned to Augustine, Calvin had to choose between the young Augustine and the late Augustine. Because the exegetical tradition is divided, Calvin's choice must reflect his theological convictions. Calvin's choice of the late Augustine, however, raises as many exegetical questions as it seems to answer.

Holder finally concludes that

Calvin followed Augustine's doctrine. With Richard Muller, it is probably more fair to say that Calvin believed that he was 
finding in Augustine a particularly fruitful presentation of the Church's doctrine. (Holder, 2005:3.)

It is finally fascinating to understand the foundation of Calvin's faith that yielded a life totally devoted to displaying the glory and majesty of God. As Piper (2000) indicates the answer lay in Calvin seeing and tasting in Scripture the majesty of God. In a moment like that God and the Word of God were so powerfully authenticated to allow him to become a servant of God and his Word for the rest of his life: this also dethroned the church as the authority that accredits the Scriptures for the saints. Fascinating are the concluding remarks of Piper (2000:124) in this respect:

Calvin, as he so often did, laid hold on Augustine to strengthen his claim that this was the historic position of the Church, in spite of the Roman Catholic teaching that the Church authorizes the Scriptures for the believer. Commenting on Augustine's view of the role of authority of the church in leading to a well-founded faith in Scripture, Calvin wrote in the 'Institutes': 'He only meant to indicate what we also confess as true: those who have not been illumined by the Spirit of God are rendered teachable by reverence for the church, so that they may persevere in learning faith in Christ from the Gospel. Thus, he avers, the authority of the church is an introduction through which we are prepared for faith in the gospel. For, as we see, he wants the certainty of the godly to rest upon a far different foundation.' (Institutes I, VII, 3.)

\section{Conclusion}

For the purposes of further discussion in South Africa on the relation between Calvin and Augustine also with regard to ecclesiology, we need to follow the worldwide discussion with far greater interest and involvement. It sadly has to be said that we have lost sight of the greater picture in this regard and that we are often stuck in our own parochial and micro agendas and issues. The need for studying and reading Augustine and Calvin also in the original languages, is even more urgent. Without doing just that, we miss out on the opportunity to really integrate their thinking and the relevance of their contributions in our local context.

It is finally important that the interest in John Calvin and his links with the church fathers and more especially with Augustine, as thoroughly explained by Van Oort, ought to be refreshed also in South Africa and ought to remain strongly in focus. It has to be said that to some extent some prominent theologians and church leaders 
from within, especially some of the Afrikaans speaking churches, have sadly lost not only their historical consciousness and appreciation with regard to the role of influential thinkers and traditions in the past, but also some of their respect for Scripture, for basic doctrinal values and for a well balanced ecclesiology. This is clearly reflected in the way that they are thinking, writing and functioning (König, 2009:294-300). It could and should even be stated in far stronger terms: seldom in the recent past has the ecclesiastical and theological situation been in such dire need of true reform and the reconsideration of some of its very basical ecclesiastical and theological tenets. If this is not going to happen it could have very negative effects for some of these churches.

May the heritage and influence of figures like Calvin and Augustine protect these churches against these serious implications.

\section{List of references}

COTTRET, B. 2000. Calvin: a biography. Grand Rapids: Eerdmans.

GANOCZY, A. \& MÜLLER, K. 1981. Calvins handschriftlichen Annotationen zu Chrysostomus: ein Beitrag zur Hermeneutik Calvins. Wiesbaden: Steiner Verlag.

GEYBELS, H. 2004. Cognitio Dei experimentalis: theologisch-epistemologische genealogie van de Christelijke religieuze ervaring. Leuven: Catholic University of Louvain. (D.Th. thesis.)

HESSELINK, I.J. 1983. On being reformed: distinctive characteristics and common misunderstandings. Ann Arbor: Servant Books.

HOLDER, R.W. 2005. Calvin's hermeneutic and tradition: an Augustinian reception of Romans 7. http://www.vanderbilt.edu/AnS/religious_studies/ SBL/Ward.htm Date of access: 16 Apr. 2009.

KÖNIG, A. 2009. Die evangelie is op die spel. Wellington: Lux Verbi.BM.

LANE, A. 1981. Calvin's use of the fathers and the medievals. Calvin theological journal, 16:149-205.

LANGE VAN RAVENSWAAIJ, J.M.J. 1990. Augustinus totus noster: das Augustin-verständnis bei Johannes Calvin. Göttingen: Vandenhoeck \& Ruprecht.

MEIJERING, E.P. 1980. Calvin wider die Neugierde: ein Beitrag zum Vergleich zwischen reformatorischem und patristischem Denken. Leiden: Nieuwkoop.

MOOI, R.J. 1965. Het kerk- en dogmahistorisch element in de werken van Johannes Calvijn. Wageningen: Veenman.

NOLL, M.A. \& NYSTROM, C. 2005. Is the reformation over? An evangelical assessment of contemporary Roman Catholicism. Grand Rapids: Baker Academic.

PIPER, J. 2000. The legacy of sovereign joy: God's triumphant grace in the lives of Augustine, Luther and Calvin. Leicester: InterVarsity.

SMITS, L. 1956-1958. Saint Augustin dans l'œuvre de Jean Calvin. Vol. 1-2. Assen: Van Gorcum. 
TODD, W.N. 1964. The function of the patristic writings in the thought of John Calvin. New York: Union Theological Seminary.

VAN OORT, J. 1992. Calvijn en Augustinus. Dutch review of church history, 72(1):92-103.

VAN OORT, J. 1997a. Calvin and the church fathers. (In Backus, I., ed. The reception of the church fathers in the West: from the Carolingians to the Maurists. Leiden: Brill. p. 661-700.)

VAN OORT, J. 1997b. De kerkvaders in reformatie en nadere reformatie. Zoetermeer: Boekencentrum.

VAN WYK, J.H. 2005. Christelike identiteit: Augustinus oor geloof, hoop en liefde. (In Van Geest, P. \& Van Oort, J., reds. Augustiniana Neerlandica: aspecten van Augustinus' spiritualiteit en haar doorwerking. Leuven: Peeters. p. 341-354.)

WALCHENBACH, J.R. 1974. John Calvin as Biblical commentator: an investigation into Calvin's use of Chrysostom as an exegetical tutor. Pittsburgh: University of Pittsburgh. (Ph.D. thesis.)

\title{
Key concepts:
}

\author{
Augustine \\ Calvin \\ church fathers \\ ecclesiology \\ Van Oort, Johannes
}

\section{Kernbegrippe:}

Augustinus

Calvyn

ekklesiologie

kerkvaders

Van Oort, Johannes 